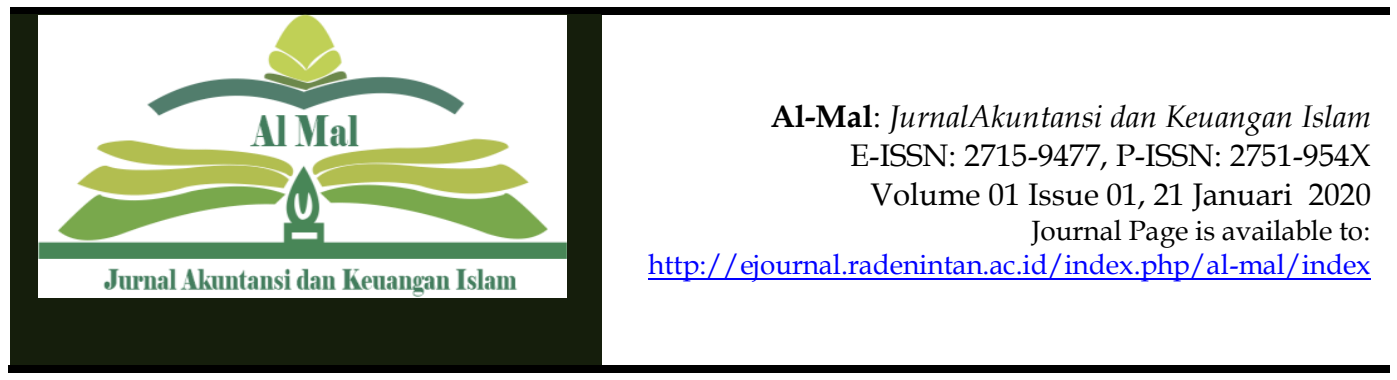

\title{
Pengaruh Penyaluran Dana Zakat, Infak Dan Sedekah (ZIS) Dan Pertumbuhan Ekonomi Terhadap Tingkat Kemiskinan
}

\author{
Eris Munandar ${ }^{*}$, Mulia Amirullah², Nila Nurochani ${ }^{3}$ \\ 1*2,3 Departement of Economics, Faculty Accounting, STEI Ar Risalah \\ Ciamis
}

\begin{tabular}{l}
\hline \multicolumn{1}{c}{ ARTICLE INFO } \\
\hline Article history: \\
Received 16-01-2020 \\
Revised 17-01-2020 \\
Accepted 17-01-2020 \\
Available 21-01-2020 \\
Revised (1) $16-05-2022$ \\
Revised (2) $11-07-2022$ \\
Accepted 11-07-2022 \\
Revised Available 17-07-2022 \\
\hline Kata Kunci: Dana ZIS, \\
Pertumbuhan Ekonomi, \\
Kemiskinan
\end{tabular}

Paper type: Research paper

Please cite this article: Munandar, E., Amirullah, M., \& Nurochani, N. "Pengaruh Penyaluran Dana Zakat, Infak Dan Sedekah (ZIS) Dan Pertumbuhan Ekonomi Terhadap Tingkat Kemiskinan" Al-Mal: Jurnal Akuntansi dan Keuangan Islam [ONLINE], Volume 01 Number 01 (Januari 21, 2020)

Cite this document:

Al-Mal 2th edition

*Corresponding author

e-mail: eris.munandar@gmail.com

\begin{tabular}{l}
\hline ABSTRAK \\
\hline Penelitian ini bertujuan untuk mengetahui \\
pengaruh penyalurana dana Zakat, infak dan \\
sedekah (ZIS) pada Badan Amil Zakat \\
Nasional dan Pertumbuhan Ekonomi \\
terhadap kemiskinan di Indonesia periode \\
2006-2017. Penelitian menggunakan metode \\
kuantitatif dengan analisis regresi linear \\
berganda. Alat olah data yang digunakan \\
yaitu SPSS. Hasil Uji T menunjukkan bahwa \\
penyaluran dana ZIS memiliki pengaruh \\
signifikan terhadap kemiskinan sedangkan \\
pertumbuhan ekonomi memiliki pengaruh \\
tidak signifikan terhadap kemiskinan di \\
Indonesia. Uji F menunjukkan bahwa \\
penyaluran dana ZIS dan pertumbuhan \\
ekonomi secara simultan berpengaruh \\
signifikan terhadap kemiskinan di Indonesia \\
periode 2006-2017. Keterbatasan pada \\
penelitian ini yaitu penggunaan variabel \\
yang mempengaruhi tingkat kemiskinan \\
ditentukan oleh penyaluran dana ZIS dan \\
pertumbuhan ekonomi sehingga membuka \\
peluang untuk peneliti-peneliti selanjutnya \\
untuk melakukan penelitian yang sama \\
dengan menambahkan varaibel-variabel \\
yang lain yang dapat mempengaruhi tingkat \\
kemiskinan. Implikasi pada penelitian ini \\
yaitu tingkat kemiskinan bisa ditanggulangi \\
oleh penyaluran dana ZIS dan meningkatkan \\
pertumbuhan ekonomi. \\
Al-Mal with CC BY license. Copyright $\odot$ 2020, the author(s) \\
\hline
\end{tabular}




\begin{abstract}
This study aims to determine the effect of the distribution of Zakat, infaq and alms (ZIS) funds at the National Amil Zakat Agency and Economic Growth on poverty in Indonesia for the period 2006-2017. The study used quantitative methods with multiple linear regression analysis. The data processing tool used is SPSS. The results of the T test show that the distribution of ZIS funds has a significant effect on poverty while economic growth has an insignificant effect on poverty in Indonesia. The F test shows that the distribution of ZIS funds and economic growth simultaneously have a significant effect on poverty in Indonesia for the 2006-2017 period. The limitation of this study is that the use of variables that affect the poverty level is determined by the distribution of ZIS funds and economic growth, thus opening up opportunities for further researchers to conduct the same research by adding other variables that can affect the poverty level. The implication of this research is that the level of poverty can be overcome by distributing ZIS funds and increasing economic growth.
\end{abstract}

\title{
Keywords : ZIS Fund, Economic Growth, Poverty
}

\section{PENDAHULUAN}

Salah satu masalah yang sering dihadapi oleh banyak negara adalah kemiskinan. Tingkat kemiskinan yang terjadi pada suatu negara menjadi salah satu ukuran untuk mengukur baik atau buruknya perekonomian suatu negara. Indonesia sebagai negara berkembang dan memiliki jumlah penduduk yang besar sehingga tidak dapat terhindar dari masalah kemiskinan tersebut. Data Badan Pusat Statistik (2018) merilis bahwa pada bulan September 2017, jumlah penduduk miskin (penduduk dengan pengeluaran per kapita per bulan di bawah Garis Kemiskinan) di Indonesia mencapai 26,58 juta orang (10,12 persen), Berbagai upaya dan usaha dari pemerintah dilakukan dalam upaya mengurangi tingkat kemiskinan, salah satunya adalah optimalisasi dana Zakat, Infak dan Sedekah (ZIS). Jika melihat perkembangan pembangunan ZIS di tanah air, maka sejak dekade 1990 telah tumbuh 
Berbagai macam lembaga pengelola zakat yang berusaha mengedepankan prinsip-prinsip manajemen modern dalam prakteknya (Beik, 2009). berkurang sebesar 1,19 juta orang dibandingkan dengan kondisi Maret 2017 yang sebesar 27,77 juta orang (10,64 persen). Ada beberapa program pengentasan kemiskinan yang telah dilakukan pemerintah pusat, baik di tingkat provinsi serta di tingkat kabupaten dan kota antara lain dalam bidang kesehatan yaitu program KIS (Kartu Indonseia Sehat), dalam bidang pendidikan yaitu PIP (Program Indonesia Pintar), serta dalam bidang sosial yaitu PKH (Program Keluarga Harapan) dan bagi para pengusaha UMKM, pemerintah memberikan bantuan modal usaha melalui program KUR (Kredit Usaha Rakyat) (Robby Achsyansyah Ishak, et. al, 2020:43). Diantara lembaga pengelola ZIS yang resmi dibentuk pemerintah adalah Badan Amil Zakat Nasional (BAZNAS).

BAZNAS merupakan badan resmi dan satu-satunya yang dibentuk oleh pemerintah berdasarkan Keputusan Presiden RI No. 8 Tahun 2001 yang memiliki tugas dan fungsi menghimpun dan menyalurkan zakat, infaq, dan sedekah (ZIS) pada tingkat nasional. Lahirnya Undang-Undang Nomor 23 Tahun 2011 tentang Pengelolaan Zakat semakin mengukuhkan peran BAZNAS sebagai lembaga yang berwenang melakukan pengelolaan zakat secara nasional.

Dalam kajian ekonomi Islam, zakat merupakan instrumen fiskal sebagai pendorong pertumbuhan ekonomi. Beberapa kajian empiris tentang hal ini telah banyak dilakukan, diantaranya oleh Ryandono (2008) dan Anggraini, dkk (2018) yang menyebutkan bahwa adanya zakat bertujuan untuk menjadikan harta senantiasa produktif dan selalu berputar. Dengan pemanfaatan dana ZIS ini diharapkan akan meningkatkan output, penyerapan tenaga kerja, pemerataan pendapatan masyarakat yang berujung pada berkurangnya tingkat kemiskinan. 
Pertumbuhan ekonomi diduga merupakan salah satu faktor penting bagi suatu negara untuk lepas dari jerat kemiskinan. Siregar dan Wahyuniarti (2006), Putro, dkk (2017) mengkaji bahwa pertumbuhan ekonomi berpengaruh signifikan terhadap penurunan jumlah penduduk miskin. Sehingga pertumbuhan ekonomi ditenggarai sebagai kekuatan pendorong untuk menekan angka kemiskinan. Suatu perekonomian dikatakan mengalami pertumbuhan atau berkembang apabila tingkat ekonomi lebih tinggi dari apa yang dicapai sebelumnya. Pertumbuhan ekonomi suatu negara atau suatu wilayah yang terus menunjukkan peningkatan menggambarkan bahwa perekonomian negara atau wilayah tersebut berkembang dengan baik. Sebaliknya apabila suatu perekonomian tersebut tidak dapat berkembang dengan baik maka akan menimbulkan masalah sosial dan ekonomi.

Kedua faktor makro ekonomi seperti yang telah dijelaskan diatas menjadi hal yang sangat penting bagi masyarakat dan pemerintah. Semua faktor tersebut dapat mempengaruhi kondisi sosial ekonomi mayarakat dan mempengaruhi pemerintah dalam pengambilan kebijakan yang tepat untuk mengatasi permasalahan kemiskinan di Indonesia.

Berpedoman pada beberapa penjelasan tersebut diatas, penelitian ini bermaksud untuk mengkaji pengaruh antara penyaluran dana ZIS dan pertumbuhan ekonomi terhadap tingkat kemiskinan di Indonesia pada periode 2006 - 2017. Secara sederhana, penelitian ini bertujuan untuk menjawab tiga pertanyaan: (1) apakah penyaluran dana ZIS berpengaruh terhadap kemiskinan di Indonesia?, (2) apakah pertumbuhan ekonomi berpengaruh terhadap kemiskinan di Indonesia?, dan (3) apakah penyaluran dana ZIS dan pertumbuhan ekonomi secara bersama-sama berpengaruh terhadap kemiskinan di Indonesia?

Untuk itu alat analisis regresi berganda digunakan dalam penelitian ini. Hal ini untuk memudahkan penulis dalam mengkaji 
seberapa besar keduanya dapat berpengaruh dalam menekan angka kemiskinan di Indonesia. Sehingga penulis berharap, hasil penelitian ini dapat berkontribusi positif dalam membangun dan memajukan perekonomian bangsa Indonesia.

\subsection{Grand Teori}

Zakat merupakan salah satu rukun Islam, bagi seorang muslim adalah suatu kewajiban yang harus dilaksanakan semata-mata pengabdian seorang hamba kepada Zat Maha Agung. Perintah melaksanakan zakat tertuang dalam Al-Qur'an surat At-Taubah ayat 103 sebagai berikut: ambillah zakat dari sebagian harta mereka, dengan zakat itu kamu membersihkan dan mensucikan mereka dan mendoalah untuk mereka. Sesungguhnya doa kamu itu (menjadi) ketenteraman jiwa bagi mereka. dan Allah Maha mendengar lagi Maha mengetahui.

Zakat sebagai sebuah kewajiban yang harus ditunaikan oleh setiap muslim yang mampu (muzakki) untuk didistribusikan kepada muslim lainnya yang kurang mampu (mustahik). Secara etimologis, zakat memiliki arti kata berkembang (an-namaa), mensucikan (at-thaharatu) dan berkah (al barakatu). Sedangkan secara terminologis, zakat mempunyai arti mengeluarkan sebagian harta dengan persyaratan tertentu untuk diberikan kepada kelompok tertentu (Mustahik) dengan persyaratan tertentu pula. (Hafidhuddin, 2002). Secara harfiah zakat juga bermakna "tumbuh dan berkembang", sehingga dapat difahami sebagai pertumbuhan kekayaan dalam arti 'nyata', pertumbuhan masyarakat secara keseluruhan atau pertumbuhan jiwa yang dimurnikan. (Ahmad dan Mahmood, 2009).

Islam mendorong setiap individu untuk berperan aktif dalam meningkatkan kualitas hidup dan menumbuhkan proses kebersamaan sosial melalui zakat, infaq dan shadaqah (Fathurrahman, 2012). Zakat menurut Sanrego dan Taufik (2016) merupakan rukun Islam yang 
merefleksikan tekad untuk menyucikan masyarakat dari penyakit kemiskinan. Zakat juga menyucikan harta orang kaya dan menyucikan masyarakat dari melakukan pelanggaran terhadap ajaran Islam akibat tidak terpenuhinya kebutuhan pokok. Kemiskinan yang merupakan problem kultural diharapkan dapat teratasi dengan semakin meningkatnya kesadaran individu yang beragama Islam dalam membayar zakat.

Beberapa kajian empiris yang berkaitan dengan zakat telah banyak dilakukan. Beik (2009) mengungkapkan bahwa zakat mampu mengurangi jumlah keluarga miskin dari 84 persen menjadi 74 persen. Kemudian dari aspek kedalaman kemiskinan, zakat juga terbukti mampu mengurangi kesenjangan kemiskinan dan kesenjangan pendapatan. Hasil analisis Romdhoni (2017) menunjukkan bahwa zakat dapat mengurangi jumlah dan persentase keluarga miskin, dan mengurangi kedalaman dan tingkat keparahan kemiskinan. Oleh karena itu, optimalisasi pengelolaan zakat, menurut Bahri (2016) menjadi suatu keharusan. Hal ini perlu dilakukan agar zakat dapat berkontribusi dalam meningkatkan kesejahteraan masyarakat. Kemiskinan yang berarti keadaan yang di mana terjadi ketidakmampuan untuk memenuhi kebutuhan dasar seperti makanan, air minum, pakaian dan tempat berlindung yang disebabkan oleh kelangkaan alat pemenuh kebutuhan hidup dan susahnya jalan kepada kesehatan, pendidikan maupun kerjaan terasa sulit untuk ditempuh bagi rakyat miskin (Henny Khamilah, 2018:315). Indikator utama keberhasilan pembangunan nasional adalah laju penurunan jumlah penduduk miskin. Efektivitas dalam menurunkan jumlah penduduk miskin merupakan pertumbuhan utama dalam memilih strategi atau instrumen pembangunan (Saharuddin Didu \& Feei Fauzi, 2016:103).

Metwally (1995) menyebutkan bahwa tingkat zakat atas asset yang tidak/kurang produktif mewakili biaya oportunitas untuk tidak 
melakukan investasi. Disisi lain, Azis, $d k k$ (2017) menjelaskan bahwa zakat akan membuat perekonomian berputar. Perputaran asset dalam perekonomian, akan meningkatkan output (perkembangan dan pertumbuhan ekonomi), penyerapan tenaga kerja, pendapatan dan kesejateraan masyarakat. Sehingga kehadiran zakat, menurut hasil kajian Anggraini, dkk, (2018) dapat mengendalikan dan mendorong pertumbuhan ekonomi.

Untuk mengetahui perbandingan antara variabel penyaluran dana ZIS dan pertumbuhan ekonomi terhadap kemiskinan, maka perlu dimodelkan terlebih dahulu menggunakan analisis regresi berganda. Setelah dilakukan analisis variabel penelitian, dilanjutkan dengan melakukan Uji-F. Kemudian dilanjutkan dengan Uji-T untuk melihat secara tersendiri variabel independent yang signifikan terhadap model penelitian. Dari hasil analisis tersebut, kemudian akan dibuat kesimpulan tentang signifikansi perbedaan penyaluran dana ZIS BAZNAS dan pertumbuhan ekonomi dalam mempengaruhi kemiskinan di Indonesia periode 2006-2017.

\subsection{Definisi Penyaluran Dana Zakat, Infaq dan Shodaqah}

Penyaluran dana ZIS merupakan besarnya dana ZIS yang disalurkan oleh BAZNAS dalam satu tahun yang dihitung dalam rupiah. Data jumlah penyaluran dana ZIS yang digunakan dalam penelitian ini berasal dari laporan keuangan BAZNAS pada tahun 2006-2017. Zakat, Infaq, Sedekah (ZIS) menjadi salah satu alat untuk mengentaskan kemiskinan. Dengan adanya dukungan dari orang-orang yang mampu mengeluarkan harta kekayaannya yang berupa dana Zakat, Infaq dan Sedekah (ZIS), maka dapat mengurangi kemiskinan dari kehidupan masyarakat (Yulfrita Adamy Yuliana \& Chelliana Adhila, 2019:4). Pelaksanaan dana ZIS yang baik dan sesuai dengan ketentuan Al-Qur'an 
dan Hadits dapat mempengaruhi pertumbuhan perekonomian di suatu negara. Sistem zakat, infak, dan shadaqah dapat memainkan peran penting dalam mendukung pembangunan ekonomi berkelanjutan dan memfasilitasi inklusi keuangan yang lebih baik (Sarah Hasanah Qoyyim \& Sisca Debyola Widuhung, 2020:55). Pembangunan yang dilakukan secara terpadu dan berkesinambungan sesuai dengan prioritas dan kebutuhan masing-masing daerah menjadi akkar dan sasaran pembangunan nasional yang telah ditetapkan melalui pembangunan jangka panjang dan jangka pendek (Muhammad Sri Wahyudi Suliswanto, 2010:358). Masalah yang sering terjadi pada perencanaan pembangunan dalam kaitannya dengan pengelolaan keuangan daerah ialah sejauh mana pengeluaran pemerintah dan pertumbuhan Ekonomi memberikan dampak terhadap kesejahteraan masyarakat (Agustien Sendouw dkk, 2019:3). Zakat, infak dan sedekah merupakan bagian yang instrumental dan zakat sendiri bagian yang fundamental dalam pilar rukun Islam, dimana posisinya menyeimbangkan horizontal dan vertikal kehidupan manusia dengan harapan ZIS tidak hanya menjadi distribusi konsumtif tetapi juga menjadi distribusi berdaya dan produktif (Rahasia Taufikk Al-Ayubbi dkk, 2021:136).

\subsection{Definisi Pertumbuhan Ekonomi}

Pertumbuhan ekonomi merupakan indikator perkembangan Produk Domestik Bruto (PDB) suatu negara dari tahun ke tahun. Untuk mengukur pertumbuhan ekonomi, nilai PDB yang digunakan adalah PDB berdasarkan harga konstan. Pertumbuhan ekonomi adalah terminologi untuk menyatakan ekspansi kapasitas produksi suatu perekonomian yang merupakan hasil output yang dibentuk oleh berbagai sektor ekonomi, sehingga dapat dilihat bagaimana kemajuan atau kemunduran yang telah dicapai di sektor ekonomi pada kurun waktu tertentu (Rudy Susanto \& 
Indah Pangesti, 2020:272). Menurut Sukino, Teori Pertumbuhan Ekonomi Neo Klasik menyatakan pertumbuhan ekonomi bergantung pada perkembangan faktor-faktor produksi yaitu ; modal, tenaga kerja dan teknologi (Chairul Nizar, dkk 2013:1). Pertumbuhan ekonomi dalam penelitian dinyatakan dalam satuan persentasi dan bersifat time series pada periode 2006-2017. Pertumbuhan ekonomi yang semakin meningkat berarti produksi barang/jasa yang dihasilkan meningkat. Dengan demikian diperlukan tenaga kerja semakin banyak untuk memproduksi barang/jasa tersebut sehingga kemiskinan berkurang dan semakin menurun (Ambok Pangiuk, 2018:45). Pertumbuhan ekonomi menjadi sebuah gambaran keadaan perokoniam di suatu daerah secara berkesinambungan yang dapat meningkatkan kemakmuran masyarakat, pertumbuhan ekonomi ditandai dengan meningkatnya jumlah barang dan jasa yang dihasilkan oleh suatu daerah (Nintan Prasetyo, 2020:56). Pertumbuhan ekonomi yang tinggi dan disertai hasil pertumbuhan ke seluruh sektor usaha sangat dibutuhkan dalam upaya menurunnkan tingkat kemiskinan. Maka untuk mempercepat penurunan tingkat kemiskinan, pertumbuhan ekonomi harus ditingkatkan (Nadia Ika Purnama, 2017:65).

Kemiskinan dipandang sebagai ketidakmampuan dari sisi ekonomi untuk memenuhi kebutuhan dasar yang diukur dari sisi pengeluaran. Dalam penelitian ini adalah persentase jumlah penduduk miskin di Indonesia pada periode 2006-2017. Kemiskinan yang terjadi dalam suatu wilayah selalu menjadi masalah yang serius karena dampak yang ditimbulkan kemiskinan begitu besar. Sehingga dari segi kemampuan ekonomi untuk memenuhi kebutuhan dasar masih sulit yang berdampak pada kekurangan gizi serta relatif mendapatkan pendidikan menengah ke bawah sehingga akan sulit bersaing di pasar tenaga kerja yang pada akhirnya akan menimbulkan masalah pengangguran (Elisabeth 
Nainggolan, 2020:90). Peningkatan peran serta penduduk miskin dapat dilakukan dengan lebih memberdayakan penduduk miskin melalui perbaikan sumber daya manusia (pendidikan dan kesehatan) dan peningkatan akses penduduk setempat terhadap sumber daya alam maupun faktor faktor produksi lainnya (Margo Tando Binti, 2016:70). Kemiskinan dapat menjadikan efek yang cukup serius bagi pembangunan manusia karena masalah kemiskinan merupakan sebuah masalah yang kompleks yang sebenarnya bermula dari kemampuan daya beli masyarakat yang tidak mampu untuk mencukupi kebutuhan pokok sehingga kebutuhan yang lain seperti pendidikan dan kesehatan terabaikan (Novita Dewi dkk, 2017:872).

\section{METODOLOGI PENELITIAN}

Dalam Penelitian ini dilakukan dengan menggunakan kuantitatif, yaitu penelitian yang menitikberatkan pada pengujian hipotesis, mengukur variabel yang sedang diteliti dan akan menghasilkan kesimpulan yang dapat digeneralisasikan, serta menggunakan alat bantu statistik.

Dalam penelitian ini, seluruh data adalah data sekunder yang diperoleh melalui media internet. Data pertumbuhan ekonomi dan kemiskinan diperoleh dari Badan Pusat Statistik yang dapat diakses melalui www.bps.go.id. Untuk data penyaluran zakat, infak dan sedekah (ZIS) berasal dari laporan keuangan Badan Amil Zakat Nasional (BAZNAS) yang dapat diakses melalui.www.pusat.baznas.go.id.

Populasi dalam penelitian ini adalah penyaluran dana ZIS yang tercatat di Badan Amil Zakat Nasional, pertumbuhan ekonomi dan kemiskinan tercatat di Badan Pusat Statistik dalam kurun waktu penelitian (2006-2017). 
Pengambilan sampel dilakukan secara subjektif oleh penulis tanpa mempertimbangkan propabilitas data terebut. Metode pemilihan sampel yang digunakan dalam penelitian ini adalah metode pemilihan sampel jenuh, yaitu seluruh anggota populasi dijadikan sebagai sampel.

Dalam penelitian ini, teknik yang digunakan adalah teknik regresi linier berganda. Berikut langkah-langkah yang diambil untuk melakukan analisis dalam penelitian ini, antara lain:

1. Menghitung rata-rata, nilai maksimum, nilai minimum, varian, dan standar deviasi setiap variabel melalui analisis statistik deskriptif

2. Uji asumsi klasik meliputi uji normalitas untuk menguji apakah dalam model regrasi variabel penganggu atau residual memiliki distribusi normal, uji multikolinieritas untuk melihat ada tidaknya hubungan linier antar variabel independent, uji autokorelasi untuk melihat apakah terdapat masalah autokorelasi atau korelasi antara variabel pengamatan, dan uji heteroskedastitas untuk melihat apakah dalam model regresi tersebut terdapat ketidaksamaan varian dari satu pengamatan ke pengamatan lainnya.

3. Uji statistik model meliputi koefisien determinasi $\left(R^{2}\right)$ untuk mengukur seberapa baik garis regresi sesuai dengan data, data analisis regresi linier berganda merupakan model analisis untuk mengetahui pengaruh variabel independen penyaluran dana ZIS dan pertumbuhan ekonomi terhadap variabel dependen kemiskinan.

4. Uji hipotesis dengan menggunakan Uji-T untuk membuktikan apakah variabel secara individu (parsial) mempengaruhi variabel dependen, dan Uji-F digunakan untuk mengevaluasi pengaruh semua variabel independen terhadap variabel dependen. 


\section{HASIL DAN PENELITIAN}

Perhitungan dalam penelitian ini diukur berdasarkan data tahunan penyaluran dana ZIS dan pertumbuhan ekonomi dari tahun 2006-2017, serta data tahunan kemiskinan dari tahun 2006-2017, sehingga setiap variabel terdapat 12 data $(\mathrm{N})$ yang diperoleh dalam penelitian ini.

\subsection{Analisis Statistik Deskriftif}

Tabel 1

Analisis Statistik Deskriptif

\begin{tabular}{|l|l|l|l|l|l|l|}
\hline & N & Min & Max & Mean & Std. Dev. & Variance \\
\hline G. & 12 & 4.63 & 6.49 & 5.6267 & .68896 & .475 \\
\hline P. & 12 & 10.64 & 17.75 & 13.0118 & 2.44521 & 5.979 \\
\hline ZIS & 12 & $1 . \mathrm{E} 10$ & $8 . \mathrm{E} 10$ & $3.78 \mathrm{E} 10$ & $1.988 \mathrm{E} 10$ & $3.953 \mathrm{E} 20$ \\
\hline N & 12 & & & & & \\
\hline
\end{tabular}

Sumber: Hasil penelitian diolah, 2018

Tabel diatas diketahui bahwa secara keseluruhan rata-rata nilai kemiskinan adalah 13,0118 dengan standar deviasi 2,44521. Jumlah minimum kemiskinan adalah 10,64 yaitu pada tahun 2017 dan jumlah maksimumnya adalah 17,75 yaitu terjadi pada tahun 2006.

\subsection{Uji Asumsi Klasik}

Pemeriksaan asumsi pertama adalah uji normalitas untuk melihat apakah dalam model regresi, variabel penganggu atau residual memiliki distribusi normal. Hasil uji normalitas Kolmogorov-Smirnov menunjukkan nilai signifikansi 0,927 lebih besar dari 0,05 sehingga hipotesis nol diterima yang artinya eror berdistribusi normal. 
Tabel 2

\begin{tabular}{|l|l|l|}
\hline \multicolumn{2}{|c|}{ Uji Normalitas Kolmogorov-Smirnov } \\
\hline \multirow{2}{*}{ N } & \multicolumn{1}{|l|}{ Unstandardized Residual } \\
\hline \multirow{2}{*}{ Normal Parameters a } & Mean & 12 \\
\cline { 2 - 3 } & Std. Deviation & 1.32680190 \\
\hline Most Extreme Differences & Absolute & .157 \\
\cline { 2 - 3 } & & \\
\cline { 2 - 3 } & Positive & .157 \\
\cline { 2 - 3 } & Negative & -.098 \\
\hline Kolmogorov-Smirnov Z & .546 \\
\hline Asymp. Sig. (2-tailed) & .927 \\
\hline
\end{tabular}

Sumber: Hasil penelitian diolah, 2018

Pemeriksaan asumsi kedua adalah uji multikolinieritas untuk melihat ada tidaknya hubungan linier antar variabel independen. Hasil yang diperoleh nilai VIF untuk dana ZIS sebesar 1,022 dan pertumbuhan ekonomi sebesar 1,022. Nilai tolerance dana ZIS sebesar 0,979 dan pertumbuhan ekonomi sebesar 0,979.

Pemeriksaan asumsi ketiga adalah uji autokorelasi untuk melihat apakah terdapat korelasi antara variabel pengamatan. Hasil uji autokorelasi Durbin-Watson mempunyai nilai 1,226 dimana nilai ini terletak lebih besar dari 4-DU = 2,4206 dan lebih kecil dari 4-DL = 3,1878 sehingga masuk ke dalam area tidak terdapat kesimpulan. Hasil uji Durbin-Watson (DW) test menunjukkan tidak ada kesimpulan. 
Tabel 4

Uji Autokorelasi Durbin-W.

\begin{tabular}{|c|c|l|}
\hline Nilai DW. & Hasil & \multicolumn{1}{c|}{ Keterangan } \\
\hline \multirow{2}{*}{1,226} & DW berada di rentang & Tidak dapat \\
& $2,4206-3,1878$ & diputuskan \\
\hline
\end{tabular}

Sumber: Hasil penelitian diolah, 2018

Pemeriksaan asumsi keempat adalah uji heteroskedastisitas untuk melihat apakah dalam model regresi tersebut terdapat ketidaksamaan varian dari satu pengamatan ke pengamatan lainnya. Hasil pengujian uji heteroskedastisitas Glesjer variabel penyaluran dana ZIS memiliki nilai signifikansi 0,180 lebih besar dari 0,05 dan nilai variabel pertumbuhan ekonomi memiliki nilai signifikansi 0,662 lebih besar dari 0,05. Maka dapat disimpulkan tidak terjadi heteroskedastisitas.

\subsection{Uji Statistik Model}

Koefisien Determinasi $\left(\mathrm{R}^{2}\right)$ digunakan untuk mengukur seberapa baik garis regresi sesuai dengan data. Hasil regresi menunjukkan nilai koefisien determinasi $\left(\mathrm{R}^{2}\right)$ adalah sebesar 0,706 atau $70,6 \%$ artinya bahwa variabel-variabel independen penyaluran dana ZIS dan pertumbuhan ekonomi mampu menjelaskan variabel dependen kemiskinan sebesar $70,6 \%$ dan sisanya $29,4 \%$ dijelaskan oleh variabel lain yang tidak dibahas pada penelitian ini.

Tabel 6

Hasil koefisien determinasi $\left(\mathrm{R}^{2}\right)$ dan adjusted $\mathrm{R}$

\begin{tabular}{|c|c|c|c|c|}
\hline Model & $\mathrm{R}$ & $\mathrm{R}$ Square & Adj. R Square & Std. Error of the Estimate \\
\hline 1 & $.840^{\mathrm{a}}$ & .706 & .640 & 1.46683 \\
\hline
\end{tabular}

Sumber: Hasil penelitian diolah, 2018

Analisis regresi linier berganda merupakan model analisis yang berfungsi untuk mengetahui variabel independen penyaluran dana ZIS 
dan pertumbuhan ekonomi terhadap variabel dependen kemiskinan. Berikut hasil pengolahannya:

Tabel 7.

Hasil Analisis Regresi Linier Berganda

\begin{tabular}{|l|l|l|l|l|l|l|}
\hline \multicolumn{2}{|l}{} & \multicolumn{2}{|l|}{ Unstand Coeffic. } & Stand. Coeffic. & $\mathrm{t}$ & Sig. \\
\cline { 2 - 8 } \multicolumn{2}{|l}{ Model } & $\mathrm{B}$ & Std. Error & Beta & & \\
\hline \multirow{2}{*}{1} & (Constant) & 95.414 & 20.708 & & 4.608 & .001 \\
\cline { 2 - 7 } & & & & -4.339 & .002 \\
\cline { 2 - 7 } & Dana ZIS & -8.189 & 1.887 & -.792 & 1.029 & .331 \\
\hline
\end{tabular}

Sumber: Hasil penelitian diolah, 2018

Berdasarkan nilai $\beta$ di atas, maka persamaan untuk regresi linier berganda adalah:

$$
Y a=95,414-8,189 \text { Dana ZIS + 0,667Growth }+\mu
$$

1. Konstanta sebesar 95,414 dan bertanda positif menunjukkan bahwa ketika penyaluran dana ZIS dan pertumbuhan ekonomi nol, maka jumlah kemiskinan akan mengalami kenikan 95,414\%.

2. Koefisien regresi $\beta_{1}$ yakni penyaluran dana ZIS sebesar 8,189 dan bertanda negatif menunjukkan jika perubahan penyaluran dana ZIS naik 1\% maka akan terjadi perubahan kemiskinan ke arah yang berbeda (turun) sebesar 8,189\%.

3. Koefisien regresi $\beta_{2}$ yakni perumbuhan ekonomi sebesar 0,667 dan bertanda positif menunjukkan jika perubahan pertumbuhan ekonomi naik $1 \%$ maka terjadi perubahan kemiskinan ke arah yang sama (naik) sebesar $0,667 \%$.

Diantara kedua variabel independen yakni variabel dana ZIS yang berpengaruh paling dominan terhadap berkurangnya tingkat kemiskinan di Indonesia. Hal ini dibuktikan melalui nilai standart coefficient beta yang paling tinggi diantara variabel independen lainnya yaitu sebesar 0.792. 


\subsection{Uji Hipotesis}

Uji $\mathrm{T}$ digunakan untuk membuktikan apakah setiap variabel independen secara individu mempengaruhi variabel dependen. Berikut adalah hasil pengolahannya:

Tabel

Hasil Uji Hipotesis (Uji T)

\begin{tabular}{|l|c|c|c|c|}
\hline Variabel Bebas & $\begin{array}{c}\text { Nilai t } \\
\text { hitung }\end{array}$ & Nilai t tabel & (a) & Sig. \\
\hline $\begin{array}{l}\text { Penyaluran } \\
\text { Dana ZIS }\end{array}$ & -4.339 & -2.262 & & 0.002 \\
\cline { 1 - 2 } $\begin{array}{l}\text { Pertumbuhan } \\
\text { Ekonomi }\end{array}$ & 1.029 & 2.262 & & 0.05 \\
\cline { 1 - 3 }
\end{tabular}

Sumber: Hasil penelitian diolah, 2018

Variabel dana ZIS mempunyai t-hitung sebesar -4.339 lebih besar nilai t-tabel sebesar -2.262 (t-hitung -4.339 > t-table -2.262) dan nilai signifikansi dana ZIS sebesar 0.002 lebih kecil dari a sebesar 0.05 (Sig 0.002 $<$ a 0.05). Hal ini menunjukkan variabel penyaluran dana ZIS (X1) berpengaruh signifikan terhadap variabel kemiskinan (Y). Sedangkan variabel pertumbuhan ekonomi mempunyai t-hitung sebesar 1.029 lebih kecil dari t-tabel sebesar 2.262 (t-hitung $1.029<$ t-tabel 2.262) dan nilai signifikansi pertumbuhan ekonomi sebesar 0.331 lebih besar dari a sebesar 0.05 (Sig $0.331>$ a 0.05). Hal ini menunjukkan variabel pertumbuhan ekonomi berpengaruh tidak signifikan terhadap variabel kemiskinan (Y).

Uji F digunakan untuk mengevaluasi pengaruh semua variabel independen terhadap variabel dependen. Berikut hasil pengolahannya: 
Tabel 9

Hasil Uji Hipotesis (Uji F)

\begin{tabular}{|c|c|c|c|}
\hline F Hitung & (a) & Sig. & F Tabel \\
\hline 10.819 & 0.05 & 0.004 & 4.10 \\
\hline
\end{tabular}

Sumber: Hasil penelitian diolah, 2018

Hasil pengujian uji F untuk seluruh variabel independen penyaluran dana ZIS (X1) dan pertumbuhan ekonomi (X2) mempunyai nilai signifikansi 0.004 lebih kecil dari a sebesar 0.05 (Sig $0.004<$ a 0.05) dengan nilai F hitung sebesar 10.819 lebih besar dari nilai $F$ tabel sebesar 4.10 (F Hitung 10.819 > F Tabel 4.10). Hal ini menunjukkan variabel penyaluran dana ZIS (X1) dan pertumbuhan ekonomi (X2) secara simultan berpengaruh terhadap variabel kemiskinan (Y). Sejumlah riset yang mempelajari fenomena kemiskinan modern sampai pada kesimpulan bahwa kemiskinan adalah problem multidimensional ketakberdayaan mencapai hidup secara layak (Fadly dkk, 2021:124).

Besarnya pengaruh penyaluran dana ZIS terhadap kemiskinan di Indonesia dapat dilihat pada tabel 8. dengan nilai t-hitung sebesar -4.339 dengan signifikansi $\mathrm{t}$ sebesar 0.002, maka sig $\mathrm{t}<\mathrm{a}$ sebesar 0,05 artinya penyaluran dana ZIS secara individu berpengaruh signifikan terhadap kemiskinan di Indonesia periode 2006-2017. Pada tabel 7 diketahui bahwa pengaruh penyaluran dana ZIS signifikan dengan arah koefisien negatif, artinya jika semakin tepat dan memadai jumlah penyaluran dana ZIS maka kemiskinan akan menurun. Hal ini tentunya sejalan dengan teori bahwa manfaat dan fungsi zakat, infak dan sedekah adalah untuk membantu orang-orang miskin agar terlepas dari benang kusut kemiskinan. 
Variabel pertumbuhan ekonomi berdasarkan hasil penelitian memiliki t-hitung sebesar 1.029 dengan signifikansi $t$ sebesar 0.331 . Sedangkan t-table dengan a 0.05 adalah 2.262 sehingga nilai t-hitung $<\mathrm{t}$ tabel $(1.029<2.262)$ dan nilai signifikansi 0.331 lebih besar dari 0.05 maka Ho ditolak. Maka dapat disimpulkan bahwa pertumbuhan ekonomi berpengaruh tidak signifikan terhadap kemiskinan di Indonesia periode 2006-2017. Pada tabel 7 diketahui bahwa pengaruh pertumbuhan ekonomi memiliki koefisien positif, artinya jika pertumbuhan ekonomi mengalami kenaikan maka kemiskinan akan meningkat. Hal ini bertentangan dengan toeri yang menyatakan bahwa kenaikan pertumbuhan ekonomi akan mengurangi kemiskinan.

Hasil penelitian menunjukkan bahwa diperoleh nilai F-hitung sebesar 10,819 dengan kriteria penolakan $H_{0}$ jika sig. $F>a$, dengan mengambil taraf signifikansi a sebesar 5\% diperoleh sig. F sebesar 0,004. Ternyata sig. F sebesar 0,004 < a 0,05 dan F-hitung 10,819 > F-tabel 4,10, maka penyaluran dana ZIS dan pertumbuhan ekonomi secara simultan berpengaruh terhadap kemiskinan. Hal ini menunjukkan bahwa hipotesis yang diajukan yaitu "penyaluran dana ZIS dan pertumbuhan ekonomi secara simultan berpengaruh terhadap kemiskinan" dapat dibuktikan.

\section{KESIMPULAN}

Berdasarkan analisis data dan pembahasan yang telah dikemukakan sebelumnya dapat ditarik kesimpulan dari penelitian ini bahwa penyaluran dana ZIS berpengaruh negatif dan signifikan terhadap kemiskinan di Indonesia periode 2006-2017. Artinya jika penyaluran dana ZIS meningkat sebesar 1\% maka kemiskinan akan menurun sebesar 8,189\%. Pertumbuhan ekonomi berpengaruh tidak signifikan terhadap kemiskinan di Indonesia. Meskipun demikian terdapat kecendrungan positif antara pertumbuhan ekonomi terhadap kemiskinan di Indonesia 
periode 2006-2017. Penyaluran dana ZIS dan pertumbuhan ekonomi berpengaruh signifikan secara simultan terhadap kemiskinan di Indonesia periode 2006-2017.

Hasil analisis penelitian ini menguatkan pendapat Beik (2009), Bahri (2016) dan Romdhoni (2017), bahwa zakat sangat berperan dalam mengurangi tingkat kemiskinan. Sehingga perlu adanya kerjasama yang baik diantara para pemangku kepentingan dalam upaya optimalisasi penghimpunan dana ZIS. Hal ini perlu diperkuat, sebab potensi zakat yang mencapai angka Rp. 217 triliun (Firdaus, dkk, 2012) tidak mungkin akan tercapai tanpa adanya kerjasama yang baik antara pemerintah, lembaga zakat, ormas Islam dan masyarakat. Sehingga Pertumbuhan ekonomi menunjukkan sejauh mana aktivitas perekonomian akan menghasilkan tambahan pendapatan masyarakat pada suatu periode tertentu. Perekonomian dianggap mengalami pertumbuhan bila seluruh balas jasa riil terhadap penggunaan faktor produksi pada tahun tertentu lebih besar daripada tahun sebelumnya (Nursiah Chalid \& Yusbar Yusuf, 2014:3). Semoga pengelolaan zakat yang baik dan professional oleh lembaga zakat dapat mendorong program-program pemberdayaan yang nyata dan langsung dapat dirasakan manfaatnya oleh masyarakat.

Tujuan dari adanya filantropi islam salah satunya yakni untuk mensejahterahkan kehidupan Umat. Dengan penyaluran dan pendistribusian dana Zakat Infaq dan Sedekah (ZIS) dengan baik dapat mendorong turunnya tingkat kemiskinan (Ira Humaira Hany \& Dina Islamiyati, 2020:119).

\section{IMPLIKASI PENELITIAN}

Implikasi pada penelitian ini yaitu tingkat kemiskinan bisa ditanggulangi oleh penyaluran dana ZIS dan meningkatkan pertumbuhan ekonomi. 


\section{REFERENSI}

Ahmad, Moid U, Athar Mahmood. 2009. Zakat fund-concept and perspective. Int. J. Monetary Economics and Finance, Vol. 2, Nos. 3/4, 2009. 197 $-205$.

Al Ayyubi, R. T. (2021). Pengaruh Distribusi Zakat, Infaq, Sedekah dan CSR Terhadap Penurunan Ketimpangan Sosial. Islamic Economics Journal, 7(2).

Ali, Nuruddin. 2016. Zakat sebagai Instrumen Kebijakan Fiskal. Jakarta: PT Raja Grafindo Persada

Anggraini, Rachmasari, Ryval Ababil, Tika Widiastuti. 2018. Pengaruh Penyaluran Dana ZIS dan Tingkat Inflasi terhadap Pertumbuhan Ekonomi Indonesia Periode 2011-2015. FALAH: Jurnal Ekonomi Syariah. Vol. 3, No.2, Agustus 2018

Azis, Harry Azhar, Tika Widiastuti, Imron Mawardi, dkk. (2017). Indonesia Zakat Development Report: Zakat dan Pemberdayaan. Surabaya: Airlangga University Press.

Badan Pusat Statistik. 2017. Laporan Perekonomian Indonesia. BPS, Jakarta

Badan Pusat Statistik. 2018. Persentase Penduduk Miskin September 2017 Mencapai 10,12 persen. Diakses dari Badan Pusat Statistik. Berita Resmi Statistik 2017. Profil kemiskiknan di Indonesia. BPS, Jakarta

Bahri S, Andi. 2016. Zakat Sebagai Instrumen Pembangunan Ekonomi Kesejahteraan Ummat. Li Falah: Jurnal Studi Ekonomi dan Bisnis Islam Volume I, Nomor 2, Desember 2016, 74 - 89.

Beik, Irfan Syauqi. 2009. Analisis Peran Zakat dalam Mengurangi Kemiskinan:

Studi Kasus Dompet Dhuafa Republika. Jurnal Pemikiran dan Gagasan - Vol II 2009.

Binti, M. T. (2017). Analisa Pengaruh Pertumbuhan Ekonomi Terhadap Penurunan Tingkat Kemiskinan Di Kalimantan Tengah. Al- 
KALAM JURNAL KOMUNIKASI, BISNIS DAN MANAJEMEN, 3(2).

Chalid, N., \& Yusuf, Y. (2014). Pengaruh tingkat kemiskinan, tingkat pengangguran, upah minimum kabupaten/kota dan laju pertumbuhan ekonomi terhadap indeks pembangunan manusia di Provinsi Riau. Jurnal ekonomi, 22(2).

Dewi, N., Yusuf, Y., \& Iyan, R. Y. (2017). Pengaruh kemiskinan dan pertumbuhan ekonomi terhadap Indeks Pembangunan Manusia di Provinsi Riau (Doctoral dissertation, Riau University).

Didu, S., \& Fauzi, F. (2016). Pengaruh jumlah penduduk, pendidikan dan pertumbuhan ekonomi terhadap kemiskinan di Kabupaten Lebak. Jurnal Ekonomi-Qu, 6(1).

Fadly, F., Inat, F., Iryanto, M., \& Quilim, C. A. (2021). Analisis Pengaruh Pembiayaan Bank Syariah, Belanja Pemerintah dan Pertumbuhan Ekonomi terhadap Tingkat Kemiskinan di Kota Ternate. Jurnal Ilmiah Ekonomi Islam, 7(1).

Fathurrahman, Ayief. 2012. Kebijakan Fiskal Indonesia Dalam Perspektif Ekonomi Islam: Studi Kasus Dalam Mengentaskan Kemiskinan. Jurnal Ekonomi dan Studi Pembangunan Volume 13, Nomor 1, April 2012, hlm.72-82

Firdaus, Muhammad, Irfan Syauqi Beik, Tonny Irawan, Bambang Juanda. 2012. Economic Estimastion and Determinations of Zakat Potential in Indonesia. IRTI Working Paper.

Ghozali, Imam. 2001. Aplikasi Analisis Multivariate Dengan Program SPSS. Semarang: Universitas Diponegoro

Hafidhuddin, Didin. 2002. Zakat Dalam Perekonomian Modern. Jakarta: Gema Insani 
Hany, I. H., \& Islamiyati, D. (2020). Pengaruh ZIS dan faktor Makro ekonomi terhadap tingkat kemiskinan di Indonesia. Jurnal Ekonomi, 25(1).

Ishak, R. A., Zakaria, J., \& Arifin, M. (2020). Pengaruh Pertumbuhan Ekonomi, Pendidikan dan Pengangguran Terhadap Tingkat Kemiskinan di Kota Makassar. Paradoks: Jurnal Ilmu Ekonomi, 3(2).

Khamilah, H. (2019). Pengaruh Pengeluaran Pemerintah, Pengangguran dan Pertumbuhan Ekonomi terhadap Tingkat Kemiskinan di Provinsi Kalimantan Selatan. JIEP: Jurnal Ilmu Ekonomi dan Pembangunan, 1(2).

Metwally, M.M. 1995. Teori dan Model Ekonomi Islam. Majalah Zakat Baznas, Edisi September 2016. PT. Bangkit Daya Insana.

Nainggolan, E. (2020). Analisis Pengaruh Pertumbuhan Ekonomi Terhadap Tingkat Kemiskinan di Provinsi Sumater Utara (20102019). Jurnal Manajemen Bisnis Eka Prasetya (Eka Prasetya Journal of Management Studies), 6(2).

Nizar, C., Hamzah, A., \& Syahnur, S. (2013). Pengaruh investasi dan tenaga kerja terhadap pertumbuhan ekonomi serta hubungannya terhadap tingkat kemiskinan di indonesia. Jurnal Ilmu Ekonomi ISSN, 2302, 172.

Pangiuk, A. (2018). Pengaruh Pertumbuhan Ekonomi Terhadap Penurunan Kemiskinan di Provinsi Jambi Tahun 2009-2013. ILTIZAM Journal of Shariah Economics Research, 2(2).

Prasetya, N. (2020). Analisis Pengaruh Pertumbuhan Ekonomi Terhadap Tingkat Kemiskinan Di Kabupaten Kediri. RISK: Jurnal Riset Bisnis dan Ekonomi, 1(2).

Purnama, N. I. (2017). Analisis pengaruh pertumbuhan ekonomi terhadap tingkat kemiskinan di Sumatera Utara. Jurnal Ekonomikawan, 17(1). 
Putro, Pilipus B.W., Sri Mintarti, Adi Wijaya. 2017. Analisis Determinasi Pertumbuhan Ekonomi Dan Kemiskinan. Jurnal INOVASI Volume 13 (2), 2017, 135-140.

Qoyyim, S. H., \& Widuhung, S. D. (2020). Analisis Strategi Penyaluran Dana Zakat, Infak, Sedekah (ZIS) dan Tingkat Inflasi Terhadap Pertumbuhan Ekonomi Di Indonesia Pada Periode 20152019. Jurnal Al Azhar Indonesia Seri Ilmu Sosial, 1(2).

Romdhoni, Abdul Haris. 2017. Zakat Dalam Mendorong Pertumbuhan Ekonomi Dan Pengentasan Kemiskinan. Jurnal Ilmiah Ekonomi Islam vol. 03. No. 01, Maret 2017, 41 - 51.

Ryandono, M.N. 2008. Ekonomi ZISWAQ (zakat,infak,shodaqoh dan wakaf). Surabaya: IFDI dan Cenforis.

Sanrego, Yulizar D., Moch. Taufik. 2016. Fiqih Tamkin: Fiqih Pemberdayaan: Membangun Modal Sosial dalam Mewujudkan Khairu Ummah. Jakarta: Qisthi Press.

Sendouw, A., Rumate, V. A., \& Rotinsulu, D. C. (2019). Pengaruh Belanja Modal, Belanja Sosial, dan Pertumbuhan Ekonomi Terhadap Tingkat Kemiskinan Di Kota Manado. Jurnal Pembangunan Ekonomi Dan Keuangan Daerah, 18(5).

Siregar Hermanto, Dwi Wahyuniarti. 2006. Dampak Pertumbuhan Ekonomi Terhadap Jumlah Penduduk Miskin. Diambil dari: http:// pustaka.blog.mb.ipb.ac.id/files/2010/06/dampakptbmbhn-ek_hermanto.pdf

Suliswanto, M. S. W. (2010). Pengaruh produk domestik bruto (PDB) dan indeks pembangunan manusia (IPM) terhadap angka kemiskinan di Indonesia. Jurnal Ekonomi Pembangunan, 8(2).

Susanto, R., \& Pangesti, I. (2021). Pengaruh Inflasi dan Pertumbuhan Ekonomi Terhadap Tingkat Kemiskinan di Indonesia. JABE (Journal of Applied Business and Economics), 7(2). 
Yuliana, Y., Adamy, Y., \& Adhila, C. (2019). Pengaruh Dana Zakat Infak dan Sedekah (ZIS) Terhadap Kemiskinan Di Kabupaten/Kota Provinsi Aceh. Jurnal Ekonomi dan Kebijakan Publik Indonesia, 6(2), 203-214. 